Available Online : https://proceeding.researchsynergypress.com/index.php/cset/index

RSF Conference Series: Engineering and Technology

ISSN 2809-6843 (Online) | 2809-6878 (Print)

Volume 1 Number 1 (2021): 486-493

\title{
Quality Improvement of Fruit Melon Varieties (Cucumis Melo L.) With Ab Mix Nutrition Formulation
}

\author{
Bambang Supriyanta ${ }^{1}$, Frans Richard Kodong ${ }^{2}$, Indah Widowati ${ }^{1}$, Farida Ariefia \\ Siswanto ${ }^{1}$ \\ ${ }^{1}$ Faculty of Agriculture UPN "Veteran" Yogyakarta, \\ 2 Faculty of Informatics Engineering, UPN “Veteran” Yogyakarta
}

\begin{abstract}
Melon (Cucumis melo L.) is a horticultural commodity that has high economic value. The sweet taste, thick flesh, crunchy texture and high quality are the reasons people are interested in melon. The increase in melon productivity can be supported by the use of superior seeds and cultivation with a hydroponic system. The purpose of this research were to obtain premium melon with high quality which are characterized by sweetness levels above 15 brix, attractive skin and flesh color, high vitamin C content, and fruit flesh thickness. The study was conducted in March to July 2021 in greenhouse CV. Agroniaga. This study used a Completely Randomized Design (CRD) with 8 treatments: N1 (Formulation 1), N2 (Formulation 2), N3 (Formulation 3), N4 (Formulation 4), N5 (Formulation 5), N6 (Control 1 AB mix Nutriponic ), N7 (Control 2 AB mix Goodplant), and N8 (Control 3 General). Quantitative data were analyzed by analysis of variance at the $5 \%$ level. If there is a significant difference between treatments, the further test is continued with the Duncan multiple range test at a significance level of 5\%. Qualitative observation data will be analyzed with descriptive statistics. Result of this research showed that N3 formula is the best to increase both harvest and quality of fruit.
\end{abstract}

Keywords: Premium Melon, Nutrient Formulation, Dutch Bucket Hydroponic

This is an open access article under the CC-BY-NC license

\section{INTRODUCTION}

Melon (Cucumis melo L.), a dicotyledonous class plant, belongs to family of Cucurbitaceae. Since it uses flower to initiate generative growth, the plant includes in the division of Spermatophyte and sub-division of Angiosperm. Melon (Cucumis melo L.) is one of horticulture of high economic value (Huda, 2015).

The conventional technic of cultivating melon makes it from low economic value (Daryono, et. al., 2016) beside poor nutrient availability. An accurate growth-phase-based fertilizing and appropriate cultivating system determine the quality of the fruit.

Hydroponics system, which is popular for its efficient resource management and food product, is a breakthrough to improve the fruit quality. Most parts of the system work automatically, depending on the need of each kind of plant, in controlling the amount of water, nutrient and photoperiod (Resh, 2013). Superior seed is another factor of productivity improvement. Crossbreed is one way to gain superior seed. It is one effort to enrich genetic variability and to gain a new superior genotype (Takdir et al., 2006).

Nutrient concentration checking based on growth phase - nursery, vegetative, and fruit forming - of melon tree is essential. The plant needs $500 \mathrm{ppm}$ of nutrient during nursery and increases 


\section{RSF Conference Series: Engineering and Technology}

Vol 1(1), 486-493

Quality Improvement of Fruit Melon Varieties (Cucumis Melo L.) With Ab Mix Nutrition Formulation

Bambang Supriyanta, Frans Richard Kodong, Indah Widowati, Farida Ariefia Siswanto

as the plant grows. In the vegetative phase it takes 800 to $1,200 \mathrm{ppm}$, and 1,700 ppm when forming fruits. (Ahmed, 2013). In addition, nutrient composition affects quality and harvest of the fruit since some particular nutrients are more needed in particular point of growth.

\section{LITERATURE REVIEW}

Simbolon and Suryanto (2018) in their article entitled The Effect of Time Interval for AB Mix Nutrients and Hydroponic Methods on Melon Plants (Cucumis melo L.), explain how the time interval for providing nutrition and the hydroponic method can increase melon yields. Based on the research objectives of Simbolon and Suryanto, they stated that the purpose of the study was to determine the effect of the time interval of giving $\mathrm{AB}$ mix nutrition and the use of hydroponic methods that were suitable for the growth and yield of melon plants. The research method they used was a split plot design with 2 factors, consisting of 6 treatments and 4 replications. The first factor is the hydroponic method with 2 levels, dutch bucket (hydroton) and substrate (cocopeat + husk charcoal). The second factor is the time interval of nutrition, interval of 2 hours, 3 hours, and 4 hours. The results of their study stated that a 2-hour nutritional interval increased fruit weight, fruit volume and fruit thickness compared to a 3-hour interval. the substrate hydroponic method can increase fruit weight, fruit volume and fruit thickness compared to the dutch bucket method.

\section{RESEARCH METHOD}

The experiment needed TDS (total dissolved solids) meter, $\mathrm{pH}$ meter, rope, a pair of scissors, calipers, plastic bags, markers, a digital scale, refractometer, raffia, a sprayer, a water pump, a PE hose, PVC pipes, censor, programing tool, nutrient buckets, internet network.

It takes Apollo melon seeds, hydroton, plant-made pesticide, rockwool, Meroke Potassium Nitrite, Meroke Calcium Nitrite, Fe EDTA, Meroke Mono Potassium Phosphate, Meroke Ammonium Sulphate, Meroke Potassium Sulphate, Meroke Magnesium Sulphate, Zn EDTA, Cu EDTA, Mn EDTA, Borat Acid, Sodium Molybdate, pH down, nutrient AB mix Goodplant, Nutriponic, and General.

This field research was conducted in a greenhouse of CV. Agroniaga using Complete Random Design (CRD) with 8 treatments, namely N1 (Formula 1), N2 (Formula 2), N3 (Formula 3), N4 (Formula 4), N5 (Formula 5), N6 (Control 1 AB mix Nutriponic), N7 (Control 2 AB mix Goodplant), and N8 (Control 3 General). Each treatment was repeated 3 times to get 24 experiment units. Each experiment unit consists of 6 plants that were taken 3 of them randomly for sample.

The variables being observed are leaf number, leaf weight, leaf diameter, fruit vertical circle, fruit horizontal circle, flesh thickness, fruit skin color, flesh color, and sweet level. 
Quality Improvement of Fruit Melon Varieties (Cucumis Melo L.) With Ab Mix Nutrition Formulation Bambang Supriyanta, Frans Richard Kodong, Indah Widowati, Farida Ariefia Siswanto

\section{FINDING AND DISCUSSION}

\section{Leaf number}

Table 1. Leaf number average of lettuce (sheets)

\begin{tabular}{clll}
\hline \multirow{2}{*}{ Treatment } & \multicolumn{3}{c}{ Time of Observation } \\
\cline { 2 - 4 } & $16 \mathrm{HST}$ & $21 \mathrm{HST}$ & $26 \mathrm{HST}$ \\
\hline N1 & $12,22 \mathrm{a}$ & $19,00 \mathrm{ab}$ & $24,89 \mathrm{a}$ \\
N2 & $11,67 \mathrm{abc}$ & $18,22 \mathrm{abc}$ & $24,33 \mathrm{a}$ \\
N3 & $11,67 \mathrm{abc}$ & $18,11 \mathrm{bc}$ & $23,67 \mathrm{a}$ \\
N4 & $12,11 \mathrm{ab}$ & $19,44 \mathrm{a}$ & $24,44 \mathrm{a}$ \\
N5 & $11,00 \mathrm{c}$ & $17,44 \mathrm{c}$ & $24,11 \mathrm{a}$ \\
N6 & $11,22 \mathrm{c}$ & $18,67 \mathrm{abc}$ & $24,33 \mathrm{a}$ \\
N7 & $11,67 \mathrm{abc}$ & $18,22 \mathrm{abc}$ & $24,22 \mathrm{a}$ \\
N8 & $11,56 \mathrm{bc}$ & $18,00 \mathrm{bc}$ & $23,67 \mathrm{a}$ \\
\hline
\end{tabular}

Notes: average followed by the same letter in each column indicates there is no significant difference according to DMRT level 5\%.

Table 1 shows that there is no significant difference in the number of leaves of melon trees in each treatment. At 16 HST, treatment N1 (12.22 sheets) has significantly more leaves than treatments N5, N6, and N8. At 21 HST, treatment N4 (19.44 sheets) significantly has more leaves than treatment N3, N5, and N8.

Melon plants at $1-26$ HST used formulation for leaves. The N1 - N7 treatment used the same nutrients, while treatment $\mathrm{N} 8$ had different nutrient. The use of 2 different nutrients did not significantly affect the number of leaves at $1-26$ HST. According to Safuan and Bahrun (2012) stated that the number and size of leaves are influenced by the growing environment and the availability of nutrients. Munawar (2011) stated that the higher the availability of nitrogen, the better the process of forming vegetative organs (leaf number).

\section{Fruit Weight}

Table 2. Melon fruit weight average (grams)

\begin{tabular}{cl}
\hline Treatment & Average \\
\hline N1 & $1581.5 \mathrm{a}$ \\
N2 3 & $1533.0 \mathrm{a}$ \\
N4 & $1749.4 \mathrm{a}$ \\
N5 & $1181.1 \mathrm{~b}$ \\
N6 & $1612.3 \mathrm{a}$ \\
N7 & $1693.3 \mathrm{a}$ \\
N8 & $1725.1 \mathrm{a}$ \\
\hline
\end{tabular}

Notes: the average followed by the same letters in each column indicates there is no significant difference according to DMRT level 5\%.

Table 3 shows that treatments N1, N2, N3, N4, N5, N6, N7, and N8 do not influence the fruit's weight. Fruit weight in treatments N1, N2, N3, N5, N6, N7, and N8 was significantly heavier than in treatment N4. Treatment N3 $(1749.4 \mathrm{~kg})$ produced the highest fruit weight compared to other treatments. This is due to the high content of potassium and phosphor in the treatment N3. Fruit weight is determined by the 

quality of fruit in the generative phase will be influenced by the availability of potassium, while phosphor plays a role in the formation of flowers and fruit. Phosphor plays a role in the formation of ATP energy which functions in metabolic reactions such as photosynthate translocation from leaves to fruit.

Based on the seed description, apollo melon has an average weight of $2 \mathrm{~kg}$. In this study the average weight of melon has not reached that weight. In addition to available nutrients, fruit weight is also influenced by environmental factors such as sunlight, humidity, and temperature. Sunlight plays an important role in the process of photosynthesis, so it affects the formation of carbohydrates and proteins during the process of fruit formation.

\section{Fruit Diameter}

Table 3. Average of melon fruit diameter ( $\mathrm{mm})$

\begin{tabular}{cl}
\hline Treatment & Average \\
\hline N1 & $143.847 \mathrm{a}$ \\
N2 & $139.823 \mathrm{ab}$ \\
N3 & $138.213 \mathrm{ab}$ \\
N4 & $129.420 \mathrm{~b}$ \\
N5 & $142.320 \mathrm{ab}$ \\
N7 & $144.327 \mathrm{a}$ \\
N8 & $144.287 \mathrm{a}$ \\
\hline
\end{tabular}

Notes: The average followed by the same letter in each column indicates there is no significance difference according to DMRT level 5\%.

Table 3 shows that treatments N1, N2, N3, N4, N5, N6, N7, and N8 do not influence significantly to the diameter of melon fruit. Fruit diameters in treatments N1 $(143,847$ $\mathrm{mm}), \mathrm{N} 6(144,327 \mathrm{~mm}), \mathrm{N} 7(144,287)$ and N8 $(144,587 \mathrm{~mm})$ were significantly larger than treatment $\mathrm{N} 4(129,420 \mathrm{~mm})$. Fruit diameter is closely related to fruit weight. The increase in the diameter of the melon causes an increase in fruit size which will affect the economic value due to an increase in yield. The high availability of phosphor in the nutrient solution causes plants to optimally absorb phosphor. According to Lingga (2010), phosphor is useful for stimulating root growth, helping assimilation, formation of cell nuclei and cell division, stimulating flowering, fruit formation, fruit and seed ripening, and strengthening plant resistance to disease. The formation of many roots allows plants to absorb more water and nutrients that dissolve with the flow of water for the flowering process and fruit formation. 


\section{Fruit Vertical Circle}

Table 4. Average of vertical circle of melon $(\mathrm{cm})$

\begin{tabular}{cl}
\hline Treatment & Average \\
\hline N1 & $50.833 \mathrm{ab}$ \\
N2 & $49.583 \mathrm{ab}$ \\
N3 & $51.417 \mathrm{ab}$ \\
N5 & $46.833 \mathrm{~b}$ \\
N6 & $52.167 \mathrm{a}$ \\
N7 & $53.167 \mathrm{a}$ \\
N8 & $51.917 \mathrm{a}$ \\
\hline
\end{tabular}

Notes: The average followed by the same letter in each column indicates there is no significance difference according to DMRT level 5\%.

Table 4 shows that treatments $\mathrm{N} 1, \mathrm{~N} 2, \mathrm{~N} 3, \mathrm{~N} 4, \mathrm{~N} 5, \mathrm{~N} 6, \mathrm{~N} 7$, and $\mathrm{N} 8$ do not influence significantly to the vertical circle of the fruit. The vertical circle of the fruit in the treatment N5 $(52,167 \mathrm{~cm}), \mathrm{N} 6(53,167 \mathrm{~cm})$, and N7 $(51,917 \mathrm{~cm})$ was significantly larger than the treatment $\mathrm{N} 4(46,833 \mathrm{~cm})$. The provision of various nutrients did not significantly affect the vertical circle of melons. According to Rahayu et. al. (2011) melon fruit circle is influenced by the number of fruits each plant. This is related to the competition between sinks, if more fruits are kept, the allocation of photosynthate will be divided among the growing fruit. In this study, only one fruit was produced each plant.

\section{Fruit Horizontal Circle}

Table 5. Average of horizontal circle of melon fruit $(\mathrm{cm})$

\begin{tabular}{cl}
\hline Treatment & Average \\
\hline N1 & $46.083 \mathrm{a}$ \\
N2 & $44.833 \mathrm{a}$ \\
N3 & $45.417 \mathrm{a}$ \\
N5 & $40.500 \mathrm{~b}$ \\
N6 & $45.333 \mathrm{a}$ \\
N7 & $48.333 \mathrm{a}$ \\
N8 & $47.333 \mathrm{a}$ \\
\hline
\end{tabular}

Notes: The average followed by the same letter in each column indicates there is no significance difference according to DMRT level 5\%.

Table 5 shows that treatments N1, N2, N3, N4, N5, N6, N7, and N8 do not influence significantly to the horizontal circle of the fruit.

Fruit horizontal circle in the treatments N1, N2, N3, N5, N6, N7, and N8 was significantly greater than in the $\mathrm{N} 4$ treatment. The provision of various nutrients did not significantly affect the horizontal circle of the melon. Melon fruit circle is influenced by thickness of the flesh, fruit diameter, and fruit weight. The addition of the flesh thickness 
Quality Improvement of Fruit Melon Varieties (Cucumis Melo L.) With Ab Mix Nutrition Formulation

Bambang Supriyanta, Frans Richard Kodong, Indah Widowati, Farida Ariefia Siswanto

or fruit diameter or fruit weight will be followed by the addition of fruit circle. Based on Laily et. al. (2018) quantitative traits that have a significant positive correlation are fruit circle to fruit thickness, fruit circle to fruit diameter, fruit circle to fruit weight.

\section{Flesh Thickness}

Table 6. Average of melon flesh thickness (mm)

\begin{tabular}{cc}
\hline Perlakuan & Rerata \\
\hline N1 & $40.663 \mathrm{a}$ \\
N2 & $40.120 \mathrm{a}$ \\
N & $41.337 \mathrm{a}$ \\
N5 & $37.243 \mathrm{a}$ \\
N6 & $39.197 \mathrm{a}$ \\
N7 & $37.973 \mathrm{a}$ \\
N8 & $39.743 \mathrm{a}$ \\
\hline
\end{tabular}

Notes: The average followed by the same letter in each column indicates there is no significance difference according to DMRT level 5\%.

Table 6 shows that treatments N1, N2, N3, N4, N5, N6, N7, and N8 do not influence significantly to the thickness of the fruit. The provision of various nutritional formulations did not significantly affect the thickness of the fruit flesh. According to Deus et. al. (2014) stated that the thickness of the melon flesh greatly determines plant production, considering that the flesh of the fruit is stored in high amounts of water. In the melon fruit trade sector, it is only based on the weight of the fruit when weighed, not paying attention to the thickness of the skin, so increasing the thickness of the flesh is very important because production will increase quantitatively. Barriyah (2015), stated that the thickness of the flesh formed in melons is influenced by the nutrients absorbed by the plant. Nutrient absorption by roots will be translocated to all plant organs. According to Ayu et. al. (2017) the results of plant assimilation are stored in the form of food reserves such as fruit, so the larger of fruit size make the flesh thicker.

\section{Sweetness Level}

Table 7. Average of sweetness level of melon (\%)

\begin{tabular}{cl}
\hline Treatment & Average \\
\hline N1 & $12.8333 \mathrm{bc}$ \\
N2 3 & $12.4167 \mathrm{c}$ \\
N4 & $14.6667 \mathrm{a}$ \\
N5 & $13.3333 \mathrm{~b}$ \\
N6 & $12.3333 \mathrm{c}$ \\
N7 & $12.6667 \mathrm{bc}$ \\
N8 & $12.5000 \mathrm{c}$ \\
\end{tabular}

Notes: The average followed by the same letter in each column indicates there is no significance difference according to DMRT level 5\%. 
Table 7 shows that treatments N1, N2, N3, N4, N5, N6, N7, and N8 do not influence significantly to the sweetness of the fruit. Sweetness level of the treatment N3 (14.6667 $\%$ ) was significantly higher than the treatment N1, N2, N4, N5, N6, N7, and N8. The treatment $\mathrm{N} 3$ contained more potassium and phosphor elements, 414 ppm potassium and $161 \mathrm{ppm}$ phosphor. The availability of sufficient $\mathrm{K}$ elements can increase the sugar content in melons which gives a sweet taste to the fruit. According to Bariyyah (2015), the availability of sufficient $\mathrm{K}$ elements in plants can improve fruit quality and production such as sugar content and fruit size. In addition, the level of maturity of the melon also affects the level of sweetness of the fruit.

Based on the seed description, apollo melon has a brix of 15 - 17\%. In this study, the average brix of melon fruit has not yet reached this level. This is presumably because the intensity of light that is too high during the day affects the temperature inside the greenhouse to be high and also the low yield of assimilate which is translocated by leaves and other plant parts to the fruit. According to Christy (2020) temperatures that are not ideal for melon plant growth and development can reduce crop production. The temperature that is too high in the plastic housing during the research will affect the decrease in production. The low assimilate translocation can be caused by several factors, including low nitrogen content and high temperature.

\section{CONCLUSION AND FUTHER RESEARCH}

Hydroponilk N3 formula is the best to increase both the production and the quality of melon fruit.

\section{Acknowledgement}

The authors should acknowledge the LPPM UPN "Veteran" of Yogyakarta that has been in great help of the fund in the form of grant for research cluster for this study, and we also acknowledgement any party who support this research.

\section{REFERENCES}

Ahmed, A.O. 2013. Good Agricultural Practices for Greenhouse Vegetable Crops. FAO. Roma.

Ayu, J., Edy S.dan Sulhaswardi. 2017. Uji Pemberian Pupuk NPK Mutiara dan Pupuk Organik Cair Nasa Terhadap Pertumbuhan dan Hasil Tanaman Melon (Cucumis melo L.). Dinamika Pertanian 33(1) : 103-114.

Bariyyah, K., S. Suparjono, dan Usmadi. 2015. Pengaruh kombinasi komposisi media organic dan konsentrasi nutrisi terhadap daya hasil tanaman melon (Cucumis melo L.). Planta Tropika Journal of Agro Science. 3(2) : 67-72.

Christy, J. 2020. Respon Peningkatan Produksi Buah Tanaman Melon (Cucumis melo L.) Secara Hidroponik. Agrium 22(3) : 150-156.

Daryono, B.S., Purnomo, Y. Sidiq, dan S.D. Maryanto. 2016. Pengembangan Sentra Budidaya

Melon di Pantai Bocor Kabupaten Kebumen melalui Implementasi Education for Sustainable Development. Jurnal Bioeksperimen 2(1) : 44-53.

Deus, D., Hariyono, K. \& Winarso, S. (2014). Penambahan nutrisi pada tiga varietas melon untuk meningkatkan hasil dan kualitas buah. Agritrop Jurnal Ilmu-ilmu Pertanian.12(2) :147-158. 
Quality Improvement of Fruit Melon Varieties (Cucumis Melo L.) With Ab Mix Nutrition Formulation Bambang Supriyanta, Frans Richard Kodong, Indah Widowati, Farida Ariefia Siswanto

Huda, A. M., W.B. Suwarno, dan A. Maharijaya. 2017. Keragaman Genetik Karakteristik Buah Antar 17 Genotipe Melon (Cucumis melo L.). J. Hort. Indonesia. 8(1) : 1-12.

Laily, N., Lestari U., dan Uyek M.Y. 2018. Kajian Sifat Kuantitatif Beberapa Genotipe Melon (Cucumis melo L.) dan Blewah (Cucumis melo varcantalupensis). Crop Agro 11(1) : $48-54$.

Lingga, P. 2010. Petunjuk Penggunaan Pupuk. Jakarta. Penebar Swadaya.

Munawar, A. 2011. Kesuburan Tanah dan Nutrisi Tanaman. Bogor. IPB Pers.

Novizan.2002. Petunjuk Pemupukan yang Efektif. Jakarta. Agromedia Pustaka.

Rahayu A, RJPJ Serhalawan, dan E. Munandar. 2011. Produksi Dan Kualitas Buah Melon (Cucumis melo L.) Pada Jumlah Buah Pertanaman yang Berbeda. Jurnal Pertanian 2(2) : 139 $-144$.

Resh, H. M. 2013. Hydroponic Food Production (7th ed.) New York. CSR Press.

Safuan, La Ode dan Andi Bahrun. 2012. Pengaruh Bahan Organik dan Pupuk Kalium terhadap Pertumbuhan dan Produksi Tanaman Melon (Cucumis melo L.). Jurnal Agroteknos. 2(2): 69-76.

Simbolon, SN., dan A. Suryanto. 2018. Pengaruh Interval Waktu Pemberian Nutrisi AB mix dan Metode Hidroponik pada Tanaman Melon (Cucumis melo L.). Jurnal Produksi Tanaman 6(9) : 2372-2381.

Takdir, A.M., Iriany, R.N., Subekti, N.A., Muzdalifah dan Marsum. 2006. Evaluasi Daya Gabung Hasil 28 Galur Jagung dengan Tester MR4 dan MR14 di Malang dan Bajeng. Jurnal Agrivigor 5(2): 173-181. 